\title{
Sulphuric acid treatment of seeds of Astragalus sinicus for eradication of sclerotia of Sclerotinia trifoliorum contaminating the seeds.
}

\author{
Takeo Aso* and Sanshi IMAI*
}

Sclerotinia rot is one of the most serious diseases of Chinese milk vetch, Astragalus sinicus. This disease first breaks out from sclerotia contaminating the seeds, in virgin fields as well as in continuously cultured fields. Up to the present time, removal of sclerotia by specific gravity, killing of sclerotia with hot water treatment, or with chemicals such as water-soluble organic mercurials, or thiram, have been reported as giving good results in the prevention of this disease.

On the other hand, the seeds of Leguminosae such as Chinese milk vetch contain large numbers of hard seeds. To hasten the germination of the hard seeds is an important problem in seeds economy. Many studies relating to this problem have been reported, and sulphuric acid treatment is said to be one of the best.

The senior author ${ }^{1)}$ examined and reported the effect of sulphuric acid upon the hard seeds and on germination of seeds of Chinese milk vetch. The authors ${ }^{7)}$ also tested the effect of sulphuric acid upon the germination of sclerotia and found that 4 to 10 hours treatments with 5 to 10 per cent sulphuric acid can be expected to sterilize sclerotia.

Tests were further made of the sulphuric acid treatment of the seeds for practical use to sterilize the sclerotia contaminating the seeds. The results are given in the present paper.

\section{Number of sclerotia contaminating the seeds}

The number of sclerotia contaminating commercial seeds of Chinese milk vetch has already been reported by Bokura ${ }^{2)}$ in 1932. He counted about 30-400 sclerotia in $100 \mathrm{~m} l$ of the seeds as contaminants. The authors also have counted sclerotia found as contaminants in some commercial seeds (Table 1).

The seed cleaning of Chinese milk vetch in Gifu Prefecture usually is done in the following way: after threshing, seeds are put in a basket, and the basket is steeped in running water of a stream stirring for about 3-5 minutes, and then the floating seeds and sclerotia are allowed to flow away. The seeds which sank are dried for commercial use.

Using the same way the authors sorted the seeds obtained from Mr. S. Imao, of Gifu Prefecture. The variety was "Daibansei-Gifurenge". Three $\mathrm{kg}$ of the seeds (about $4.2 l$ ) were soaked in water in a tub, and stirred 2 minutes. The floating seeds and sclerotia were removed to another tub and again treated with water for 3 minutes in the same way, and then the remaining floating sclerotia and seeds were removed. The seeds and sclerotia were air-dried indoors, and the weight and volume of each lot of the seeds and sclerotia were measured. Each lot of sclerotia were screened by three sieves: $1 \mathrm{~mm}, 1.5 \mathrm{~mm}$, and $2 \mathrm{~mm}$ in diameter (Table 2). In 5 minutes soaking, 99.2 per

\footnotetext{
* Agricultural Institute, Yokohama National University, Yokohama, Japan.
} 
Table 1. Number of sclerotia contaminating the commercial seeds ${ }^{a}$ of Chinese milk vetch.

\begin{tabular}{cc|c|c|c}
\hline \hline Year of harvest & $\begin{array}{c}\text { Vclume of seed tested } \\
(\mathrm{m} l)\end{array}$ & Number of sclerotia & $\begin{array}{c}\text { Number of sclerotia in } \\
100 \mathrm{~m} l \text { of seed }\end{array}$ \\
\hline \multirow{3}{*}{1958} & a & 580 & 854 & 148 \\
& b & 900 & 2,714 & 302 \\
\hline & c & 430 & 393 & 136 \\
\hline & d & 4,200 & 5,697 & 367 \\
\hline
\end{tabular}

a Seeds were obtained from Yukijirushi Seeds Co. (a), Sakata Seeds Co. (b), and Gifu Green Manure Co. (c-f)

Table 2. Percentage of volume of seeds and number of sclerotia which sank and floated in water soaking.

\begin{tabular}{c|c|c|c|c|c|c|c}
\hline \hline \multirow{2}{*}{\begin{tabular}{c|c|c|c|c} 
Minutes \\
soaked
\end{tabular}} & $\begin{array}{c}\text { Sank or } \\
\text { floated }\end{array}$ & $\begin{array}{c}\text { Seeds in } \\
\text { weight } \\
(\%)\end{array}$ & $\begin{array}{c}\text { Smaller } \\
\text { than } \\
1 \mathrm{~mm}\end{array}$ & $1-1.5 \mathrm{~mm}$ & $1.5-2 \mathrm{~mm}$ & $\begin{array}{c}\text { Larger } \\
\text { than } \\
2 \mathrm{~mm}\end{array}$ & $\begin{array}{c}\text { Sotal } \\
\text { Torotia (\%) }\end{array}$ \\
\hline $0-2$ & Sank & 83.4 & 1.5 & 4.8 & 1.0 & 0.4 & 7.7 \\
\hline $\begin{array}{c}0-2 \text { floated } \\
\text { but } \\
0-5 \text { sank }\end{array}$ & 15.8 & 0.9 & 4.7 & 3.5 & 1.4 & 10.6 \\
\hline 5 & Floated & 0.8 & 2.2 & 27.1 & 35.8 & 16.5 & 81.7 \\
\hline
\end{tabular}

cent in weight of the seeds and 18.3 per cent in number of the sclerotia sank. The sclerotia contaminating the sunken seeds were 136 in number per $100 \mathrm{ml}$ of seeds.

\section{Relation of scarification procedure and of size of sclerotia to germinaion of the sclerotia}

Sclerotia used in this study were those grouped by screening in the preceding study, and another sample found as contaminants in the seeds received from the Gifu Green Manure Co. Ltd., which were cultured by Mr. N. Hayashi, in 1959. A half of the latter was subjected to mechanical scarification by a machine of that Company by which the commercial seeds have usually been scratched for rendering hard seeds germinable. The sclerotia of the latter source were also screened into three groups.

Regardless of whether the sclerotia were scratched or not, those smaller than $1.0 \mathrm{~mm}$ decayed in large percentage than the larger one, and formed fewer apothecia. There seemed to be a tendency that the scarification of sclerotia together with seeds is not so evidently injurious to the germination of sclerotia as to be expected for the practical purposes and the floating sclerotia germinate more vigorously in a certain degree than the sunken ones. 


\section{The value of sulphuric acid treatment of the seeds as a control measure for sclerotinia rot}

As reported in the previous two reports ${ }^{1,7)}$, the best result for chemical eradication of sclerotia was obtained in 4-7 hour treatments with 5-10 per cent sulphuric acid solutions, but from the effect on seeds germination, the length of time for treatment should be between 3 and 5 hours. Accordingly the authors adopted 3.5-4.5 hour treatments with 7-8 per cent acid solutions as the standard method for eradication of sclerotia contaminating the seeds.

The procedure of sulphuric acid treatment was as follows: 1 liter of seeds were put in a 4 liter China pot, to which added 1 liter of a given sulphuric acid solution, stirred frequently during a selected time, while the control used 2 liters of water in stead of sulphuric acid. After treatment, the seeds were washed five times using water about 2 times volume of the seeds, and then further washed four times at intervals of 10 minutes by changing the water. The washed seeds were airdried indoors. Acid treatment was done on 2 Oct., 1960.

Table 3. Volume of acid solution which was decreased during the treating.

\begin{tabular}{c|c|c|c}
\hline $\begin{array}{c}\text { Concentration of } \\
\text { acid (\%) }\end{array}$ & Hours treated & $\begin{array}{c}\text { Decreased volume } \\
\text { by soaking }(\mathrm{m} l)^{a}\end{array}$ & $\begin{array}{c}\text { Minimum volume to be } \\
\text { required for soaking } 1,000 \mathrm{~m} l \\
\text { of seeds }(\mathrm{m} l)\end{array}$ \\
\hline 7 & 3.5 & 200 & 560 \\
& 4 & 230 & - \\
& 4.5 & 225 & 585 \\
\hline 8 & 3.5 & 200 & 545 \\
\hline Water & 4 & 212 & 595 \\
\hline
\end{tabular}

a Seeds used were 1 liter, acid solution 1 liter and water 2 liters.

1) Volume of acid solution to be used

\section{for treatment}

The volume of acid solution decreases by seed soaking, since there is absorption of solution by seeds and sclerotia. The approximate volume required for full soaking of seeds was sought for practical purposes. Table 3 shows the results of this study. The minimum volume of acid solution for treating seeds is considered to be about 60 per cent of the volume of the seeds under the conditions of the solution and the length of times.

\section{2) Germination of seeds}

Air-dried seeds, 200 for each lot, were sown in shallow pots containing 600 grams of soil on 8 Oct., 1960 and placed indoors. Graph 1 shows

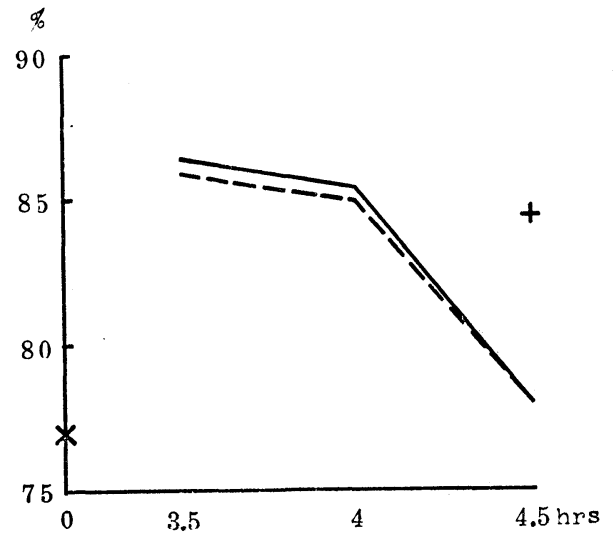

Graph 1. Effect of sulphuric acid treatment on the seed germination.

$-7 \%$ solution, ... $8 \%$ solution.
$+\quad$ Control (water soaking 4.5 hours)
$\times \quad$ Control (non soaking) 
the results of the examination on 22 Oct., 1960. 3.5 and 4 hour treatments show better germination in both percentage and energy than the water-soaked control, but 4.5 hour treatment was poorer than the others.

\section{3) Effect upon the yield of the plant}

Each plot was sown in triplicate in ridges $12 \mathrm{~cm}$ wide and $180 \mathrm{~cm}$ in length, with 600 seeds, after inoculation with Rhizobium, on 10 Oct., 1960, and reaped on 17 May, 1961. Fertilizers were used at a rate of $7.5 \mathrm{~kg}$ for both $\mathrm{P}_{2} \mathrm{O}_{5}$ and $\mathrm{K}_{2} \mathrm{O}$ per 10 a. All treated plots, except the 4.5 hour treatment with 8 per cent solution, gave the same or greater yields than the control (Table 4).

Table 4. Effect of seed treatment with acid solution upon the yield of Chinese milk vetch.

\begin{tabular}{|c|c|c|}
\hline$\underset{(\%)}{\text { Concentration of acid }}$ & Hours soaked & Yield $\underset{(\mathrm{kg})^{a}}{\operatorname{per}} 1.65 \mathrm{~m}^{2}$ \\
\hline \multirow{3}{*}{7} & 3.5 & 8.899 \\
\hline & 4 & 8.948 \\
\hline & 4.5 & 8.813 \\
\hline \multirow{3}{*}{8} & 3.5 & 8.798 \\
\hline & 4 & 10.136 \\
\hline & 4.5 & 8.648 \\
\hline \multirow{2}{*}{0 (Control) } & Soaked water 4.5 & 8.775 \\
\hline & Non-soaked & 8.325 \\
\hline
\end{tabular}

a Yield is mean value of the triplicate.

Table 5. Effect of acid solution upon the sclerotial germination.

\begin{tabular}{|c|c|c|c|c|c|c|c|c|c|c|}
\hline \multirow{2}{*}{$\begin{array}{c}\text { Concentra- } \\
\text { tion of acid } \\
(\%)\end{array}$} & \multirow{2}{*}{$\begin{array}{l}\text { Hours } \\
\text { soaked }\end{array}$} & \multicolumn{4}{|c|}{$\begin{array}{c}\text { December } \begin{array}{c}24, \\
\text { after) }\end{array}\end{array}$} & \multicolumn{5}{|c|}{ April 10, 1961 (171 days after) } \\
\hline & & $\begin{array}{l}\mathrm{A}^{a} \\
(\%)\end{array}$ & $\mathrm{B}^{b}$ & $\mathrm{C}^{c}$ & $\begin{array}{l}\mathrm{D}^{d} \\
(\%)\end{array}$ & $\begin{array}{l}\mathrm{A} \\
(\%)\end{array}$ & B & $\mathrm{C}$ & $\mathrm{D}$ & $\begin{array}{c}\mathrm{E}^{e} \\
(\%)\end{array}$ \\
\hline \multirow{3}{*}{7} & 3.5 & 一 & 一 & - & 75 & - & - & - & 85 & 15 \\
\hline & 4 & - & - & - & 74 & - & - & - & 91 & 9 \\
\hline & 4.5 & - & - & - & 77 & 一 & - & - & 87 & 13 \\
\hline \multirow{3}{*}{8} & 3.5 & - & - & - & 73 & - & - & - & 92 & 8 \\
\hline & 4 & - & - & - & 78 & - & - & - & 92 & 8 \\
\hline & 4.5 & - & - & 一 & 76 & - & - & - & 92 & 8 \\
\hline \multirow{2}{*}{$\begin{array}{c}0 \\
\text { (Control) }\end{array}$} & $\begin{array}{c}\text { Soaked } \\
\text { water } 4.5\end{array}$ & 74 & 232 & 113 & 5 & 95 & 261 & 137 & 5 & 0 \\
\hline & Non-soaked & 77 & 187 & 94 & 3 & 97 & 223 & 121 & 3 & 0 \\
\hline
\end{tabular}

Sclerotia used for each lot were 100 in number.

a Percentage of sclerotia which germinated by apothecial stalk.

$b$ Number of apothecial stalks which germinated from the sclerotia used.

- Number of apothecia.

d Percentage of sclerotia which were rotted and degenerated.

e Percentage of sclerotia which neither completely rotted nor germinated.

\section{4) Germination of sclerotia}

Sclerotia which were treated together with seeds, 100 for each lot, were put to the germination by apothecia in Liebenberg's apparatus on 21 Oct., 1960, and examined on 24 Dec. and 10 April 
for germination (Table 5).

No germination was observed in the sclerotia of the lots treated with sulphuric acid: percentage of decay and degeneration were 73 to 78 per cent after about 2 months, reaching to 90 per cent in the following April. The rest remained ungerminated without degeneration. The sclerotia in the untreated lots gave 74-77 per cent germination in December, and 95-97 per cent in April.

Iida and Suzuki ${ }^{6}$ ) reported that Sclerotinia trifoliorum could be distinguished into two strains by the time of germination of sclerotia, namely autumnal and vernal. In the present experiment, germination occurred in both seasons, but about 75 per cent was autumnal.

\section{5) Outbreak of disease in the field}

The experimental field was divided into $3.3 \mathrm{~m}^{2}$ for each plot, which was surrounded by barley sowed on 2 Sept., designed to prevent dissemination of spores. Untreated seeds of $4 \mathrm{~m} l(2.8 \mathrm{~g})$, from which the sclerotia were completely removed, to $1 \mathrm{~m}^{2}$ in the center of the plot, and twenty treated sclerotia in an area of $30 \mathrm{~cm}^{2}$ at the center of the $1 \mathrm{~m}^{2}$ seeds bed were sown on 10 Oct., 1961, and then covered with soil by a sieve at a depth so as to be slightly covered by the soil. As control, untreated sclerotia were sown in the same way.

In the control plots germination of sclerotia was observed in December, but the disease did not appear macroscopically, because the host plant was too small and too scattered to be attacked by the fungus. The disease became serious in March. Table 6 shows the results of measurement on April 12.

Treated sclerotial plots were free from disease, but untreated plots were severely diseased, not only in the center in which sclerotia were sown but also in the neighbouring area up to $25 \mathrm{~cm}$ apart from the border of areas in which sclerotia were sown. The plant of these diseased areas were severely decayed.

Effect of sclerotinia rot on yield of Chinese milk vetch may vary with the time of disease

Table 6. Outbreak of disease in the field.

\begin{tabular}{|c|c|c|c|c|c|c|}
\hline Plot & $\begin{array}{c}\text { Concentration } \\
\text { of } \mathrm{H}_{2} \mathrm{SO}_{4}\end{array}$ & Hours soaked & & $\begin{array}{c}\mathrm{A}^{a} \\
(\mathrm{~cm})\end{array}$ & $\begin{array}{c}\mathrm{B}^{b} \\
(\mathrm{~cm})\end{array}$ & $\begin{array}{c}\mathrm{C}^{\circ} \\
(\mathrm{cm})\end{array}$ \\
\hline \multirow{6}{*}{$\begin{array}{l}\text { Sclerotia } \\
\text { treated }\end{array}$} & & 3.5 & & - & - & - \\
\hline & $7(\%)$ & 4 & & - & - & - \\
\hline & & 4.5 & & - & - & - \\
\hline & & 3.5 & & - & - & - \\
\hline & $8(\%)$ & 4 & & - & - & 一 \\
\hline & & 4.5 & & - & - & 一 \\
\hline \multirow{6}{*}{$\begin{array}{l}\text { Sclerotia } \\
\text { untreated }\end{array}$} & \multirow{3}{*}{ Water soaked } & \multirow{3}{*}{4.5} & $1^{d}$ & 25 & - & $10(15), 15(15)$ \\
\hline & & & 2 & 25 & - & $20(15), 10(15), 10(20)$ \\
\hline & & & 3 & 30 & - & $20(20), 10(10)$ \\
\hline & \multirow{3}{*}{ Not soaked } & & 1 & 10,10 & 15,9 & $10(10), 10(15), 15(20)$ \\
\hline & & & 2 & 25 & - & $15(15), 10(20)$ \\
\hline & & & 3 & 30 & 10 & $10(25), 20(25), 20(15), 25(5)$ \\
\hline
\end{tabular}

a Diameter of diseased area in the area in which sclerotia were placed.

b Diameter of diseased areas which are adjacent to the diseased area of A.

- Diameter of diseased areas occurring apart from the diseased area of $\mathrm{A}$, with the distance from the area A shown in parenthesis.

d 1,2 and 3 in the control show the replications of each plot. 
Table 7. Effect of the disease on the yield of the plant.

\begin{tabular}{c|c}
\hline \hline Plot $^{a}$ & Yield in $1 \mathrm{~m}^{2}(\mathrm{~kg})$ \\
\hline Sclerotia untreated & 2.216 \\
\hline Sclerotia treated & 6.783
\end{tabular}

$a$ In the treated sclerotial plot the sclerotia were soaked for 4 hours in 8 per cent sulphuric acid solution, but in the untreated sclerotial plct the sclerotia were nct treated. 20 sclerotia were applied to each plot as inocula.

outbreak, density of the stand of milk vetch, intensity of disease, etc. The results of a preliminary test in 1959-60, performed by inoculating with the sclerotia as mentioned above, are presented in the Table 7 .

\section{Consideration}

The seeds of Chinese milk vetch usually contain about 30 per cent hard seeds. The recovery of these hard seeds to regular germination is an important problem of seed economy. Seeds of this plant which have been commonly sold in Japan always contain enough sclerotia to bring about a primary outbreak of sclerotinia rot, namely 90 to 350 or more sclerotia in $100 \mathrm{~m} l$ of seeds. Unless these sclerotia contaminating the seeds are removed or killed, they become a causal agent for the primary outbreak of the disease in virgin field.

For the purpose of recovery of hard seeds to regular germination, sulphuric acid solution must be in 80 per cent or higher concentration, but for the purpose of disinfection of sclerotia contaminating the seeds, the treatment should be 3-4 hours in 7-8 per cent acid solution. Thus the authors could not kill two birds with one stone; however, a treatment with 7 or 8 per cent sulphuric acid solution during 3.5-4 hours prevents the outbreak of disease by sclerotia contaminating the seeds, and accelerates germination of seeds and growth of seedling.

\section{Summary}

1. This paper deals with the results on seed treatment of Astragalus sinicus L. with sulphuric acid solution for destroying the sclerotia of Sclerotinia trifoliorum Eriks. contaminating the seeds.

2. Commercial seeds of $A$. sinicus in Japan have contained sclerctia of $S$. trifoliorum from 90 to 350 or more in number per $100 \mathrm{ml}$ of the seeds.

3. The larger the sclerotia, either scratched with sand or not, the greater the germination by apothecia, while the smaller sclerotia decayed more easily during germination.

4. The minimum volume of acid solution for treating seeds was about 60 per cent of the volume of the seeds. The seeds treated with 7 or 8 per cent solution of sulphuric acid for 3.5 and 4.0 hours gave a higher percentage and greater energy of seed germination than those of untreated seeds. Moreover almost all the sclerotia treated decayed and degenerated, and did not germinate by apothecia, while with untreated sclerotia 95-97 per cent of the sclerotia used germinated. In field experiments, the treated seed plots were free from disease at all, but the untreated seed plots were severely diseased. Preliminary experiments showed that the yield from treated seeds was as much as 3 times greater than that of untreated seeds.

5. From above data, we should expect good results for destroying the sclerotia mixed with 
the seeds of $A$. sinicus, by seed treating for 3.5 to 4 hours with $7 \mathrm{cr} 8$ per cent solutions of sulphuric acid.

(Received Jul. 9, 1962)

\section{References}

1. Aso, T. (1960). Seiken Ziho $11: 55-62$ (in Japanese).

2. Bokura, U. (1932). Materials for Improv. Agr., Ministry of Agr. and Forestry, No. 46, 23 p. (in Japanese).

3. Hashioka, Y., Ikegami, H. and Siraki, S. (1955). Res. Bull. Fac. Agr. Gifu Univ. 5: 21-30.

4. Hashioka, Y., Ikegami, H. and Siraki, S. (1956). Ibid. $6: 50-57$.

5. Hashioka, Y., Ikegami, H. and Siraki, S. (1957). Ibid. $8: 1-7$.

6. Iida, W. and Suzuki, Y. (1955). Jour. Hokuriku Agr. 3:62-66 (in Japanese).

7. Imai, S. and Aso, T. (1962). Ann. Phytopath. Scc. Japan $27: 223-230$.

8. Matsuura, Y. (1946). Report Yamagata Agr. Exp. Sta. 155p. (in Japanese).

9. Matsuura, Y. (1948). Tohoku Agr. $2: 46-50$ (in Japanese).

\section{和文摘要 レンゲ種子に混在するレンゲ菌核病菌の菌核の殺滅を目的と} した種子の硫酸処理

$$
\text { 麻 生 武 夫*.今 井三 子* }
$$

1. 本邦市販のレンゲ種子中には菌核病菌の菌核が $100 \mathrm{ml}$ 中に 90 350 粒めるいはさらに多数混在し, この菌核によつて処女地に菌核病が発生する。

2. 菌核は硬実対策としての種子の砂ずりの有無にかかわらず, 大形のものほど盤果の発生が多く, 小形 の菌核は発芽の途中で腐敗するものが多い。

3. 硫酸液による種子処理に要する液量は，種子容量の $60 \%$ が最少量である。 $7 〜 8 \%$ 液で $3.5 \sim 4$ 時 間種子を処理することによつて, 混在するほとんど全部の菌核は死隇し, 湯での発病は阻止されるのみな らず, 種子の発芽率および発芽勢は無処理のものより高く, ほ場実験では処理区は無処理区の 3 倍に及ぶ収 量をあげた。

4. 以上の結果から, レンゲ種子を $7 \%$ あるいは $8 \%$ の硫酸液で, 3.5 あるいは 4 時間処理することに よつて, 種子に混在する菌核による発病は防止し得ることが期待できる。（*横浜国立大学農学教室）

サツマイモ黒斑病り病塊茥におけるウンベリ

フェロンとスコポレチン合成の分析的研究

Minamikawa, T., Akazawa, T., and Uritani, I. (1963). Analytical study cf umbelliferone and scopoletin synthesis in sweet potato rcots infected by Ceratocystis fimbriata. Plant Physiology 38 (5) : 493-497.

り病塊茎組織中のクマリン化合物の動きを薄層ク ロマトグラフ法を用いて経時的に追求した。農林 1 号(抵抗性品種)では，接種後12時間でウンベリフェ ロン（以下U）が著しく増加し，4 日目で最高とな り以後急激に減少する。スコポレチン（以下S）は 1 日の誘導期を経て合成が始まり 4 日目で最高とな

\section{紹介}

る。しかしSはUより量的には少なく，4 日目でU の約半量である。無接種区では U, S ともごくわず かしか認められない。品種間を比較してみると, 農 林10号 (抵抗性) ではUの合成が著しく, 接種後 4 日目で無接種区の 45 倍, 農林 4 号 (感受性) では 14 倍である。 S は農林 10 号で27倍, 農林 4 号では 3.5 倍 である。次に病原菌をふりまぜ培養で 2 日培養した 後U, Sを加え, 更に 4 日培養を続けU, Sを定量 してみると，Uは約 $20 \%, \mathrm{~S}$ は約 $90 \%$ 分解されてい ることがわかつた。クマリンを加えない区ではU, $\mathrm{S}$ の産生が認められず, また $\mathrm{U}, \mathrm{S}$ 相互の変化もみ られなかつた。 (佐藤 善司) 